\begin{abstract}
Iranica
Abstracta Iranica Revue bibliographique pour le domaine irano-aryen

Volume 32-33 | 2013

Comptes rendus des publications de 2009-2010
\end{abstract}

\title{
Fabrizio Speziale. India xxxiii. Indo-Muslim Physicians
}

\section{Suzanne Kurz}

\section{(2) OpenEdition \\ 12 Journals}

\section{Electronic version}

URL: http://journals.openedition.org/abstractairanica/40722

DOI: 10.4000/abstractairanica.40722

ISSN: 1961-960X

Publisher:

CNRS (UMR 7528 Mondes iraniens et indiens), Éditions de l'IFRI

\section{Printed version}

Date of publication: 1 December 2013

ISSN: 0240-8910

\section{Electronic reference}

Suzanne Kurz, "Fabrizio Speziale. India xxxiii. Indo-Muslim Physicians », Abstracta Iranica [Online], Volume 32-33 | 2013, document 404, Online since 01 July 2016, connection on 03 October 2020. URL : http://journals.openedition.org/abstractairanica/40722 ; DOI : https://doi.org/10.4000/ abstractairanica.40722

This text was automatically generated on 3 October 2020.

Tous droits réservés 


\title{
Fabrizio Speziale. India xxxiii. Indo- Muslim Physicians
}

\author{
Suzanne Kurz
}

\section{REFERENCES}

Fabrizio Speziale. « India xxxiii. Indo-Muslim Physicians ». Encyclopaedia Iranica, Online Edition, 15 July 2009, available at http://www.iranica.com/articles/india-xxxiii-indomuslim-physicians

1 This article on Indo-Muslim physicians is valuable for researchers working in the vast field of the history of Indo-Muslim medicine. It is the only existing overview, both succinct and analytical, of major trends and developments in this field. The author describes general trends while providing results from research so as to structure his account systematically. For example, he points out that Iranian emigrants set the trend for commentaries on Arabic classics such as Avicenna's Qānūn in 16th century India, while Persian works on Indian medicine were mostly authored by Muslims born or raised in India. Such new works rather than translations of Sanskrit treatises were the main medium for adapting Indian medical knowledge to Persophone culture. From the Mogul period onwards, non-Muslim Indians were also writing on Avicennian medicine, but Persian works on Indian medicine were still being mostly written by Muslims. For the author, this introduction of Indian medical knowledge to Muslim culture via Persian was a major "translation movement" in the field of medicine and the main "process of translation" from a non-Muslim scientific tradition in the modern age. This is definitely true if we take "translation" to mean a transfer of knowledge. On the pragmatic motivation of this transfer and the great interest of Persophone authors in pharmacology (the need to integrate Indian drugs instead of Greco-Islamic ones that were not available in India), the author refers to the relevant sources.

2 After this instructive overview, the author deals with important authors and works, starting with the north Indian predecessors of the Moguls and then moving on to the 
Deccan sultanates. A large section is devoted to developments under the Moguls. It reveals the author's deep understanding of the medical and other scientific texts from all periods of Persophone culture in India. Its value lies in the information provided about a reasonably made selection of the most important authors and works. At the end of the article is a shorter section on the Princely States and a look at the colonial period, when the main language of medical literature shifted to Urdu. This article is the best treatment of the subject currently available; it evinces the author's broad knowledge and experience with research.

\section{AUTHORS}

SUZANNE KURZ

Ruhr-Universität, Bochum 